\title{
4. PALEOGENE AND NEOGENE LARGER FORAMINIFERS FROM THE QUEENSLAND PLATEAU: BIOSTRATIGRAPHY AND ENVIRONMENTAL SIGNIFICANCE ${ }^{1}$
}

\author{
C. Betzler ${ }^{2}$ and G.C.H. Chaproniere ${ }^{2}$
}

\begin{abstract}
At several sites drilled during Ocean Drilling Program (ODP) Leg 133 on the Queensland Plateau, larger shallow-water benthic foraminifers have been recovered from neritic carbonates and from turbidites that consist of shallow-water-derived material Within neritic sediments, the occurrence of different faunal associations provides a tool for biostratigraphic subdivision.

Three main phases of neritic deposition occurred on the Queensland Plateau. An Eocene episode is characterized by subtropical to temperate associations (Operculina-Nummulites Facies). It is unconformably followed by a late Oligocene to middle Miocene episode that contains tropical to subtropical associations (Spiroclypeus Facies, Larger Foraminifer-Coral Facies, Austrotrillina Facies, Flosculinella-Amphistegina Facies, Marginopora Facies, and Miogypsina Facies).

After the middle Miocene, most of the Queensland Plateau carbonate platform was drowned. The post-middle Miocene to Holocene reefs, which are characterized by a geographically more restricted distribution, shed neritic material including larger benthic foraminifers into adjacent basinal areas. This process is associated with a partial reworking of middle Miocene deposits containing Lepidocyclina (Nephrolepidina).
\end{abstract}

\section{INTRODUCTION}

Before drilling operations during ODPLeg 133 on the Queensland Plateau, little information was available concerning the stratigraphy of this carbonate platform. Initial drilling in the vicinity of the Queensland Plateau (DSDP Site 209; Burns, Andrews, et al., 1973) did not penetrate any shallow-water carbonates. Chaproniere (1983) described larger benthic foraminifer occurrences in dredge samples from different localities on the Queensland Plateau. He showed that Eocene and upper Oligocene to lower Miocene neritic deposits were present in this area. Palmieri $(1973,1984)$ described larger benthic foraminifer-bearing faunas from the Capricorn Basin south of the Queensland Plateau. He showed that the oldest neritic deposits there are of late Oligocene age.

The purposes of this study are (1) to describe the distribution of larger benthic foraminifers from the shallow-water sediments of the Queensland Plateau recovered by drilling during Leg 133; (2) to establish the biostratigraphy of the neritic sediments; and (3) to discuss some environmental aspects.

The East Indian Letter Stage Classification for the Tertiary, as modified by Adams (1970, 1984), Jenkins et al. (1985), Chaproniere (1981, 1984), and Wonders and Adams (1991) has been used for the larger benthic foraminifer biostratigraphy. In addition, Parameters $\mathrm{F}$ (Chaproniere, 1980, 1984) and dc (e.g., Van der Vlerk et al., 1973) have been employed for the classification of specimens of Lepidocyclina (Nephrolepidina). Planktonic foraminifer zonations and calcareous nannoplankton zones for the Queensland Plateau sites follow the biostratigraphy in Davies, McKenzie, Palmer-Julson, et al. (1991).

Paleoenvironmental interpretation follows the models of Haak (in Wiedicke, 1987), Chaproniere (1975), Carozzi et al. (1976), Epting (1980), and Hallock and Glenn (1985).

The larger benthic foraminifers in the studied samples occur in unlithified and lithified deposits. The unlithified samples (20 to 40 $\mathrm{cm}^{3}$ ) were washed over a $63-\mu \mathrm{m}$ sieve using standard preparation techniques, and all specimens were picked out. Equatorial sections of

\footnotetext{
'McKenzie, J.A., Davies, P.J., Palmer-Julson, A., et al., 1993. Proc. ODP, Sci. Results, 133: College Station, TX (Ocean Drilling Program).

${ }^{2}$ Geologisch-Paläontologisches Institut, Senckenberganlage 32-34, 60054 Frankfur am Main II, F.R.G.

${ }^{3}$ Bureau of Mineral Resources, Geology and Geophysics, GPO Box 378, Canberra. ACT 2601, Australia.
}

a representative number of Lepidocyclina (Nephrolepidina) (average $15 /$ sample) were generated. Because of the small sample volume of the indurated samples, only random thin sections have been analyzed and described.

\section{A SUMMARY OF LITHOSTRATIGRAPHY (SITE DESCRIPTIONS)}

Six sites were drilled on the Queensland Plateau (Fig. 1). Drilling at Sites $811 / 825$ on the western margin of the plateau penetrated a 385-m-thick sequence of neritic to bathyal calcareous sediments. Above $150.22 \mathrm{mbsf}$, only a small number of larger benthic foraminifers are present; these occurrences are in strata of reworked shallow-water material interbedded in pelagic and hemipelagic sediments. Below this level, the faunas contain abundant to very abundant specimens.

Sites 812,813 , and 814 are located on the southern margin of the plateau at the southwestern edge of the Tregrosse/Lihou/Coringa Bank complex. At Site 812, drilling penetrated a 300-m-thick succession of upper bathyal to neritic calcareous deposits. Larger benthic foraminifers occur below 83.64 mbsf. Dolomitization affects, to various degrees, the preservation of the faunas in the interval between $105.5 \mathrm{mbsf}$ and the bottom of the hole.

Site 813 contains $231.5 \mathrm{~m}$ of an upper bathyal to neritic sequence. Larger benthic foraminifers occur between $195.7 \mathrm{mbsf}$ and the bottom of the hole. However, dolomitization has strongly affected the faunal preservation.

As in the previously described holes, Site 814 contains a $300-\mathrm{m}$ thick, deepening-upward (neritic to upper bathyal) sequence of calcareous sediments. Larger benthic foraminifers are recorded between $57.19 \mathrm{mbsf}$ and the bottom of the hole.

Site 824 is located on the western slope of the Queensland Plateau, west of Holmes Reef. The entire 431-m-thick neritic to bathyal calcareous sequence (deepening-upward) contains larger benthic foraminifers. In the upper part, the specimens occur in layers of reworked shallow-water material, whereas the occurrence in the lower part of the section is thought to be in situ.

In addition to the Queensland Plateau material, spot samples from coarse-grained strata at Sites 817 and 823 were analyzed for larger benthic foraminifers. Site 817 lies on the northern side of the Townsville Trough, on the lower slope of the Queensland Plateau, southwest of the Tregrosse/Lihou/Coringa Bank complex. The deposits drilled at this site consist of carbonate platform slope deposits (early Miocene 


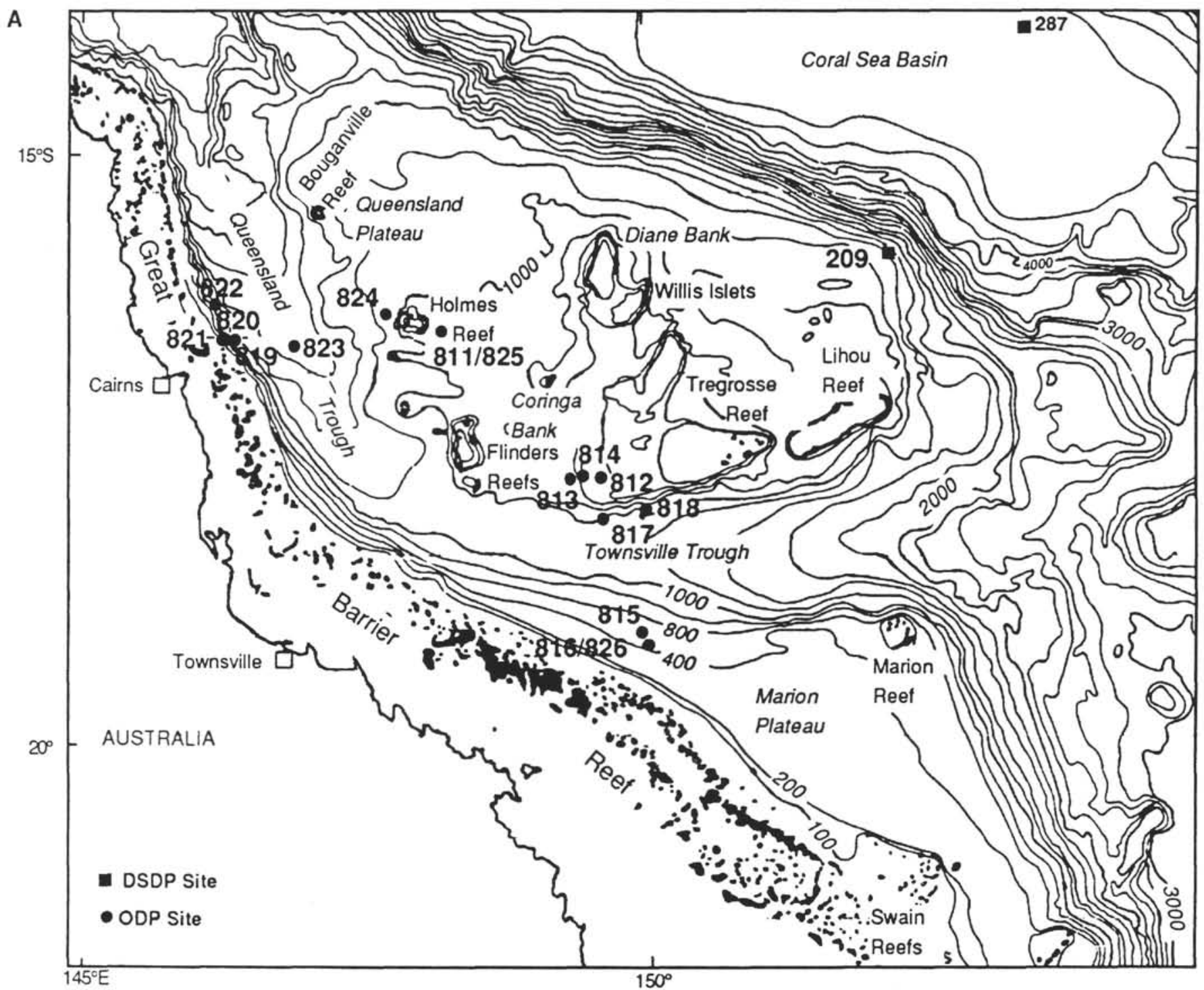

Figure 1. A. Location map of the drilling sites of Leg 133 and location of Site 209 (DSDP Leg 21). B. Overview of the lithostratigraphy at Sites $811 / 825$ and 824.

to Pleistocene age). The sequence provides a record of the variation in flux of platform-derived material containing larger benthic foraminifers vs. pelagic carbonates in the slope deposits. Site 823 is located in the central-western Queensland Trough, toward the deepest part of the basin. The succession consists of an alternation of middle Miocene to Pleistocene hemipelagic deposits with abundant gravityflow deposits that contain clasts and fragments of neritic limestones.

\section{BIOSTRATIGRAPHY OF THE NERITIC SUCCESSIONS}

\section{Sites 811/825}

Thirty-two samples were studied from Sites 811/825. Larger benthic foraminifers at this site occur in neritic deposits (lower to middle Eocene and lower Miocene), as well as in redeposited shallow-water sediments interbedded in hemipelagic to pelagic deposits.

The oldest larger benthic foraminiferal assemblage was assigned an age of early or middle Eocene (Fig. 2) based on the presence of Discocyclina sp. in Sample 133-825B-7R-1, 59-61 cm (Pl. 1, Figs. 1-3) and Nummulites (Sample 133-825B-5R-CC, 5-8 cm) (PI. 1, Figs. 4 and 5). The Nummulites is best referred to as a precursor of
N. sublaevigatus (H. Schaub, pers. comm., 1991). The presence of Morozovella (Sample 133-811B-22X-CC) above these samples provides evidence for an age of middle Eocene or older.

The middle Eocene interval is overlain by upper Oligocene (planktonic Zone P22) fine-grained, unconsolidated packstones having abundant planktonic foraminifers. Within this interval, larger benthic foraminifers appear (fragments of small Lepidocyclina [Nephrolepidina] broken along the equatorial plane) in two samples: 133$811 \mathrm{~B}-21 \mathrm{X}-1,40-46 \mathrm{~cm}$, and $-20 \mathrm{X}-1,20-25 \mathrm{~cm}$. In both samples, the specimens show equatorial chambers that are arranged in intersecting curves. The average value for Parameter $\mathrm{F}$ is $\sim 1$, pointing to a late Oligocene age (lower Te).

The next younger occurrence of larger benthic foraminifers is in Samples 133-825A-16X-CC, 0-31 cm, -15X-CC, and-16X-CC. The first sample consists of a lithified grainstone having abundant bryozoans, rare Operculina complanata, rare Miogypsina, and rare fragments of Lepidocyclina. The other samples are unconsolidated grainstones to rudstones with abundant Lepidocyclina (Eulepidina ephippioides [Jones and Chapman], Nephrolepidina sumatrensis [Brady], N. praehowchini [Chaproniere]; Pl. 3, Figs. 1-5), very rare to rare Victoriella conoidea (Rutten), Heterostegina, and Cycloclypeus. This faunal assemblage was assigned to the upper Te, which 
B
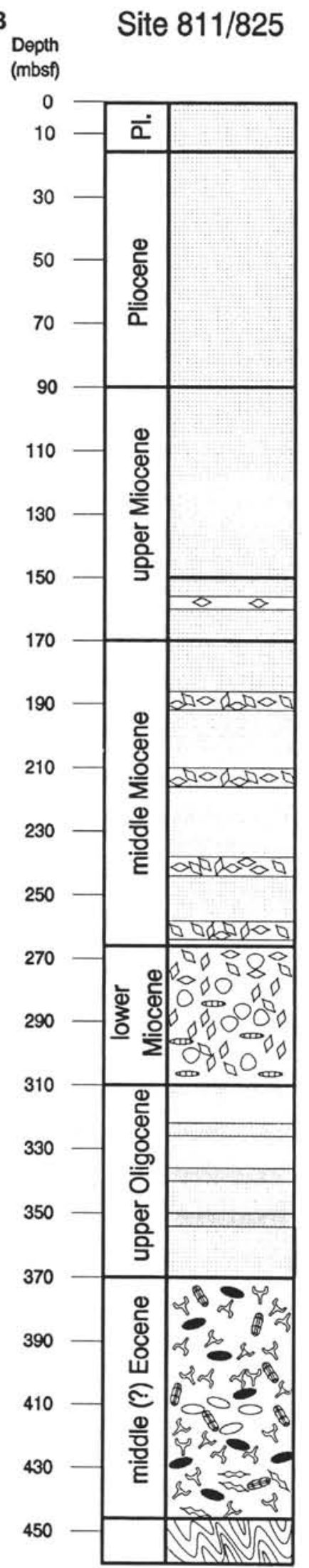

Figure I (continued).
Site 824

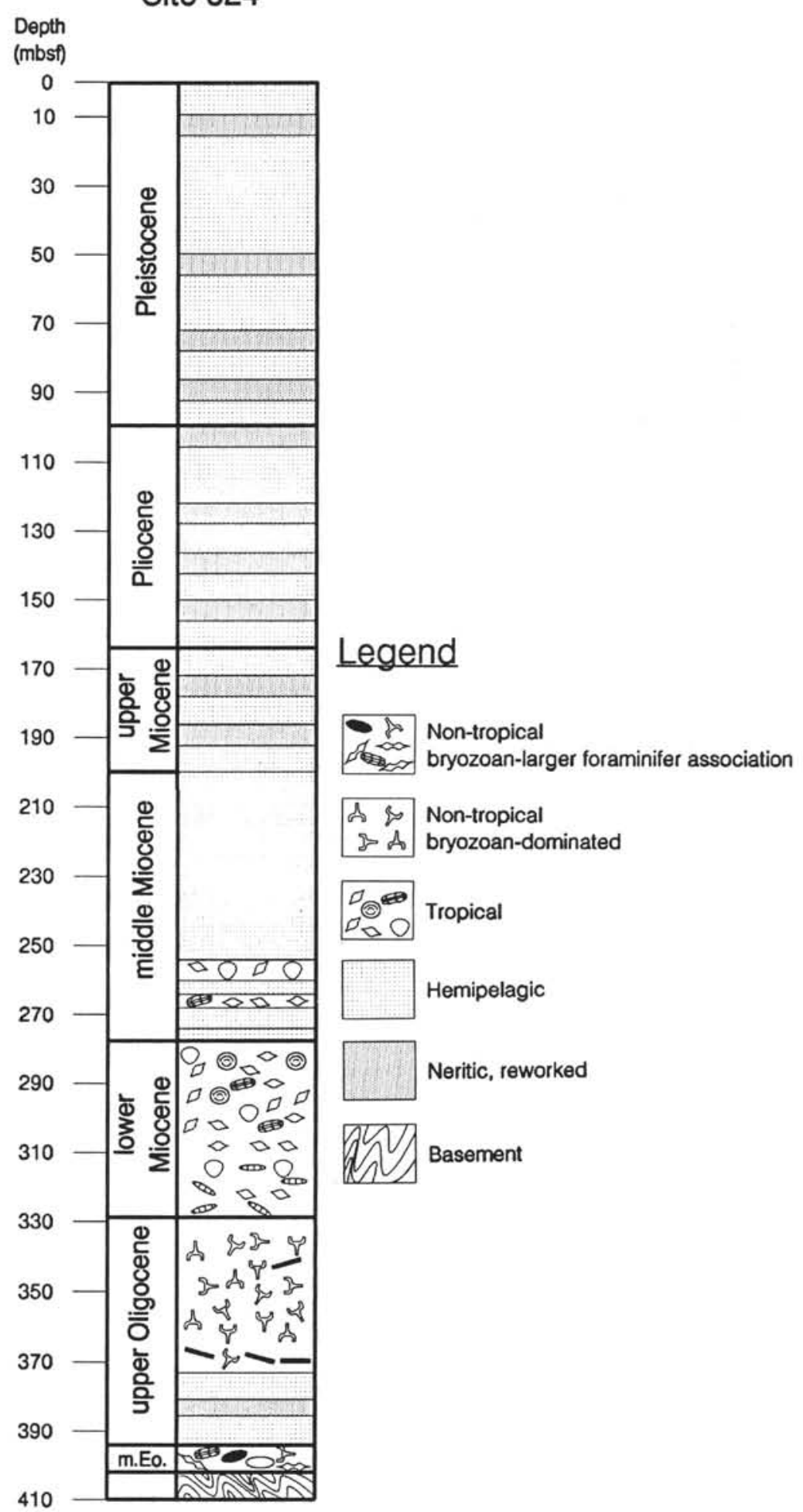




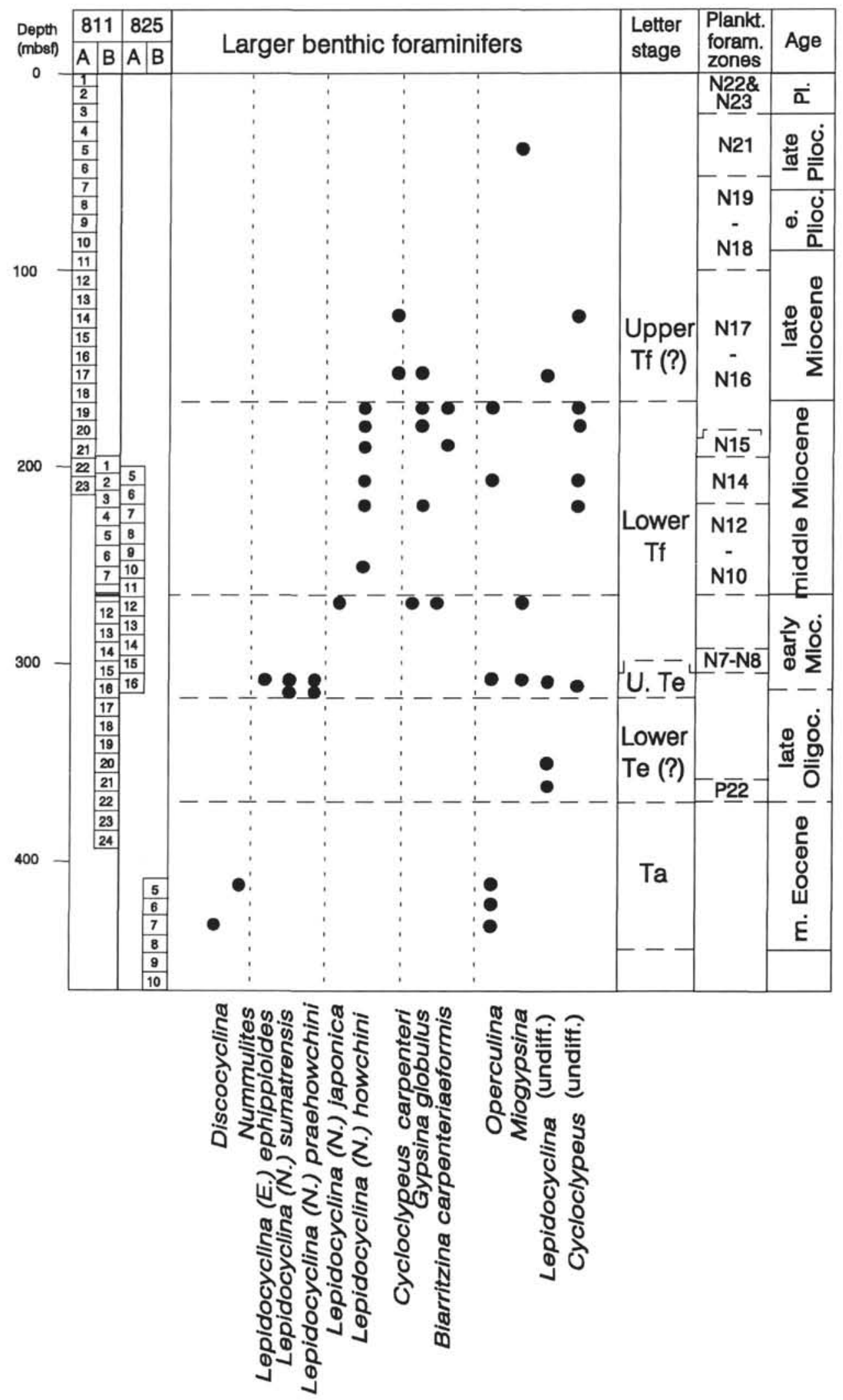

Figure 2. Distribution of larger benthic foraminifers at Sites 811/825. 
encompasses the uppermost Oligocene to lower Miocene. The mean value of Parameter $\mathrm{F}$ for the measured specimens of Lepidocyclina (Nephrolepidina) in both samples is $2.06(\mathrm{n}=6)$.

The occurrence of planktonic foraminifers of the N7-N8 planktonic foraminiferal zone together with Lepidocyclina (E. ephippioides) (LAD: top N3/N4, upper Te; Chaproniere, 1981) in Sample 133-811B-15X-CC (Pl. 3, Fig. 3) suggests the existence of a hiatus that represents the planktonic foraminifer Zones N5 and N6. The mixing of specimens from both biozones might be either a result of the reworking of E. ephippioides into the younger sediments or a consequence of the low core recovery (1\%) in Core 133-811B-15X, resulting in a "telescoping effect." At the corresponding depth (307 mbsf), the velocity log of Hole $825 \mathrm{~B}$ shows a strong velocity increase (Davies, McKenzie, Palmer-Julson, et al., 1991), pointing to the presence of a well-cemented layer that may correspond to a hardground representing a condensed section and/or a layer affected by meteoric diagenesis.

The lower-middle Miocene boundary, which coincides with a cemented hardground visible in the velocity log, is between Cores 133-811B-7V and 133-811B-9V. Larger benthic foraminifers in the older sample include: Lepidocyclina (N.) japonica (Yabe), Cycloclypeus carpenteri (Brady) (Pc 11-15, $\left.\mathrm{Spc}_{(4+5)}=15-20\right)$, Gypsina globulus (Reuss), and Miogypsina. The younger sample contains abundant Lepidocyclina (N.) howchini (Chapman and Crespin), Heterostegina, and Miogypsina. The mean value of Parameter $\mathrm{F}$ for $L$. $(N$.) howchini is relatively high $(4.61 ; \mathrm{n}=5)$, which places these specimens within the middle Miocene. This age assignment is supported by a Zone N10-N12 planktonic foraminifer fauna in Core 133-811B-8X.

The remaining middle Miocene samples are dominated by frequent-to-abundant $L$. (N.) howchini (Pl. 3, Fig. 6), rare to frequent Cycloclypeus carpenteri, rare Gypsina globulus, and rare Biarritzina carpentariaeformis (Halkyard).

Redeposited $L .(N$.$) howchini also is seen in layers consisting of$ reworked shallow-water deposits within the upper Miocene, which is indicated by calcareous nannoplankton and planktonic foraminifers (Neogloboquadrina acostaensis). However, it should be noted, that generally the appearance of $N$. acostaensis may depend on the existence of warm surface-water temperatures (C. Müller, pers. comm., 1992). As a consequence, in this case, the separation of the middle from upper Miocene may be somewhat ambiguous. $L$. (N.) howchini is abundant in Samples 133-811A-19H-1, 173-178 cm, and -17H-2, $72-74 \mathrm{~cm}$. Above these cores, Lepidocyclina occurs only in small numbers. The highest occurrence of Lepidocyclina (Nephrolepidina) is seen in Sample 133-811 A-5H-1, 33-37 cm, in the upper Pliocene.

\section{Site 824}

Forty-three samples were studied from Site 824. Larger benthic foraminifers appear throughout the section but are confined to neritic deposits and redeposited shallow-water sediments (Fig. 3).

The oldest larger foraminiferal association was assigned to the Eocene and consists of poorly preserved, fragmented Nummulites, Discocyclina, and Operculina in a calcarenite (Core 133-824C-17R). By analogy with the age assignment of the lowermost marine interval at Sites $811 / 825$ and at DSDP Site 209, we postulate that this association at Site 824 is early to middle Eocene.

The calcarenites are overlain by upper Oligocene (N3-N4) bryozoan rudstones with rare Operculina, followed by a lower Miocene unit of inner neritic carbonates (Cores 133-824C-8R to 133-824A$24 \mathrm{X}$ ) with abundant larger benthic foraminifers.

The lowermost analyzed sample of this interval is Sample 133$824 \mathrm{C}-8 \mathrm{R}-1,67-71 \mathrm{~cm}$. The upper Te fauna consists of Spiroclypeus, Lepidocyclina (Eulepidina) ephippioides, L. (Nephrolepidina) sumatrensis, Austrotrillina striata (Todd and Post) (PI. 4, Figs. 3-6), Miogypsina (Miogypsinoides) dehaartii (van der Vlerk) (Pl. 4, Fig. 1), Sherbornina, acervulinid foraminifers and Operculina. Other typical upper Te larger benthic foraminifers within this interval are Flosculinella globulosa (Rutten) (Pl. 5, Figs. 1 and 2), Miogypsina thecideaeformis (Rutten) (Pl. 4, Fig. 2), $L$. (N.) praehowchini, and $L$. (N.) japonica.

The boundary between the upper Te and lower $\mathrm{Tf}$ stages is in Core $133-824$ A-24X. In this core two different facies were recovered. The older, which contains an Upper Te association, consists of recrystallized packstones with partially leached components and geopetal peloidal mud infills in vugs (evidence for meteoric diagenesis). The younger facies consists of a weakly lithified wackestone to packstone with Cycloclypeus carpenteri, Lepidocyclina (N.) howchini, bryozoans, planktonic foraminifers, and red algae. The presence of $L$. $(N$.) howchini indicates that this association belongs to the lower $\mathrm{Tf}$ stage. It has been interpreted as a middle to outer neritic association because of the occurrence of planktonic foraminifers. The top of this second Miocene build-up episode is seen in Sample 133-824C-1R-CC, a hardground with planktonic foraminifers (Globorotalia praemenardii, Zones N10- N12) in borings. In the same core, there is a sample that consists of a nonrecrystallized wackestone to floatstone with frequent Miogypsina thecideaeformis.

The remainder of the larger benthic foraminifer faunas (upper Miocene to recent) occur in reworked layers of neritic deposits interbedded in pelagic foraminiferal and nannoplankton oozes (Pl. 5, Fig. 5). The faunas contain rare to very rare specimens: Lepidocyclina (Nephrolepidina), Gypsina globulus, Marginopora, Operculina, and Alveolinella (Fig. 3).

\section{Site 812}

Sixty-three samples were analyzed from Site 812. Dolomitization below $105.5 \mathrm{mbsf}$ has largely destroyed the primary fabric of the middle Miocene neritic deposits. The only nondolomitized sample that contains identifiable larger benthic foraminifers is Sample 133812B-16R-CC, a floatstone. The association contains abundant Lepidocyclina (Nephrolepidina) and Katacycloclypeus. The mean value of Parameter F for L. (Nephrolepidina) is $\sim 4$, which led us to assign this sample a middle Miocene age. In the other samples, acervulinid foraminifers, Operculina, and Amphistegina were recognized.

Above the dolomitized interval, between Samples 133-812C$12 \mathrm{H}-1,144-159 \mathrm{~cm}$, and $-5 \mathrm{H}-4,64-69 \mathrm{~cm}$, a unit having abundant to very abundant Cycloclypeus carpenteri occurs (the biometry will be the subject of further studies).

\section{Site $\mathbf{8 1 3}$}

Eight samples were analyzed from the dolomitized section below 160 mbsf (middle Miocene [?]). The original depositional fabric of this possibly neritic unit has been destroyed, while only very poorly preserved tests of Cycloclypeus and amphisteginids are present. No further age determination can be made.

\section{Site 814}

Twenty-three samples were analyzed from this site. From 145.7 mbsf (base of Core 133-814A-17X) to the bottom of the hole, the faunas are poorly preserved as a consequence of dolomitization. In the samples analyzed from this interval, Cycloclypeus, Operculina, and rare Lepidocyclina (Nephrolepidina) howchini occur. Parameter $\mathrm{F}$ for one specimen of $L$. (N.) howchini in Sample 133-814A-23X-CC is $\sim 4$, which places this sample in the middle Miocene.

In the upper part of the middle Miocene section (Cores 133-814A$16 \mathrm{H}$ through $-13 \mathrm{H}$ ), the faunas are better preserved. The unlithified packstones contain varying proportions of larger benthic foraminifers. Generally, the associations are dominated by Cycloclypeus carpenteri $\left(\mathrm{Pc} \geq 8, \mathrm{Spc}_{(4+5)} \geq 7\right)$ with rare to frequent $L$. (N.) howchini. Parameter $\mathrm{F}$ for these specimens is $4-5$, which places them in the middle Miocene. 


\section{BETZLER, G.C.H. CHAPRONIERE}

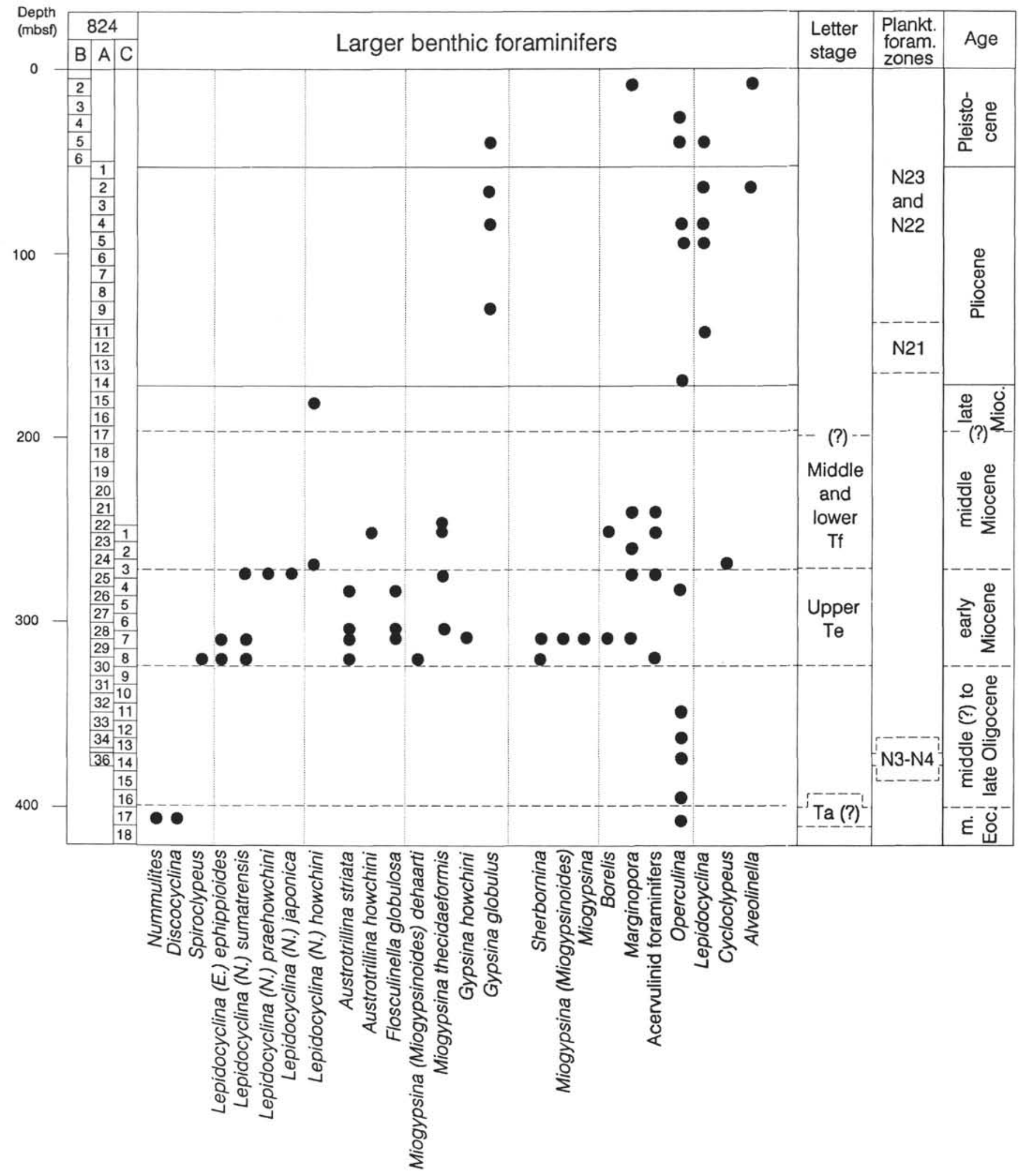

Figure 3. Distribution of larger benthic foraminifers at Site 824. 
Only a few samples of the remainder of the succession were analyzed. Sample 133-814A-12H-2, 10-15 cm, contains Cycloclypeus and Lepidocyclina (Nephrolepidina). These specimens of Nephrolepidina have hexagonal equatorial chambers and a mean value for parameter $F$ of $3.6(n=5)$. They are similar to specimens from Indonesia defined as $L$. $(N$.) martini (Schlumberger) by van Vessem (1978).

Three samples from Core 133-814A-8X contain abundant planktonic foraminifers, rare Cycloclypeus, rare amphisteginids, fragments of echinoids, and Halimeda.

\section{Sites 817 and 823}

At Site 817 , the larger benthic foraminifers occur in turbidites that consist of redeposited neritic material. Table 1 gives a summary of the early and middle Miocene age taxa.

At Site 823 (Table 2), the larger benthic foraminifers occur within the middle to upper Miocene succession in reworked clasts. The faunal associations found within the clasts indicate that the lower and middle Miocene sediments have been affected by this reworking.

\section{PALEOENVIRONMENTS OF THE NERITIC SUCCESSIONS}

Because of poor core recovery in the neritic deposits, it was not possible to determine facies cycles, which would allow one to reconstruct the depositional systems. For this reason, each facies will be described on its own, and a paleoenvironmental classification of the larger benthic foraminifer-bearing deposits will be proposed. Only faunal associations that are considered to be in situ will be discussed here.

The Eocene and Miocene facies are treated separately because the respective composition of the neritic larger benthic foraminifer associations differs considerably (see e.g., Adams, 1984). Lepidocyclina, Austrotrillina, and Miogypsinoides are genera that appeared in the Indo-Pacific Realm during the late Oligocene; Flosculinella, Marginopora, and Katacycloclypeus are genera that appeared during the early and middle Miocene (see Adams, 1984).

\section{Paleogene (Eocene)}

Two Eocene larger benthic foraminifer-bearing facies were distinguished (Table 3 ). These occur in well-lithified layers interbedded within weakly cemented bryozoan-dominated grainstones.

\section{Operculina Facies}

The first assemblage consists of lithified grainstones with abundant operculinas and minor Heterostegina. Varying amounts of bryozoans, red algal and echinoid debris, and small benthic and planktonic foraminifers constitute the remainder of the samples.

\section{Nummulites-Operculina Facies}

This assemblage is present in only one sample. It is composed of a grainstone with rare-to-frequent Nummulites, Operculina debris, bryozoans, echinoid debris, small benthic foraminifers, and micritized bioclasts.

\section{Interpretation}

A model for the distribution of Paleogene larger benthic foraminifer associations has been proposed by Luterbacher (1984), who described an Operculina-Discocyclina association having small specimens in the inner-to-outer neritic zone (30-60 m water depth). This depth assignment seems to be supported by the absence of representatives of shallower water deposits (e.g., Alveolina) and the occurrence of some
Table 1. Occurrence of larger benthic foraminifers, Site 817.

\begin{tabular}{|c|c|c|c|c|c|c|c|}
\hline $\begin{array}{l}\text { Core, section, } \\
\text { interval }(\mathrm{cm})\end{array}$ & 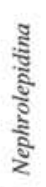 & 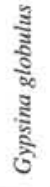 & 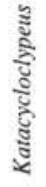 & 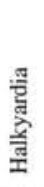 & 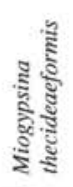 & $\begin{array}{l}\frac{5}{5} \\
\frac{5}{2} \\
\frac{2}{8} \\
\frac{2}{2}\end{array}$ & 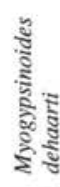 \\
\hline $\begin{array}{l}133-817 \mathrm{~A}-11 \mathrm{R}-1, \\
10-12 \\
-19 \mathrm{R}-1,24-26 \\
-19 \mathrm{R}-1,14-19 \\
-20 \mathrm{R}-1,17-19 \\
-21 \mathrm{R}-\mathrm{CC} \\
-23 \mathrm{R}-\mathrm{CC} \\
-23 \mathrm{R}-1,24-26 \\
-26 \mathrm{R}-2,41-44 \\
-27 \mathrm{R}-1,13-16 \\
-27 \mathrm{R}-1,17-20 \\
-27 \mathrm{R}-\mathrm{CC} \\
-34 \mathrm{R}-1,44-48\end{array}$ & $\begin{array}{l}\mathrm{X} \\
\mathrm{X} \\
\mathrm{X} \\
\mathrm{X} \\
\mathrm{X} \\
\mathrm{X} \\
\mathrm{X} \\
\mathrm{X} \\
\mathrm{X} \\
\mathrm{X} \\
\mathrm{X}\end{array}$ & $\mathrm{X}$ & $\begin{array}{l}x \\
x\end{array}$ & $\begin{array}{l}X \\
X \\
X\end{array}$ & $X$ & $\begin{array}{l}X \\
X \\
X\end{array}$ & $X$ \\
\hline
\end{tabular}

Table 2. Occurrence of larger benthic foraminifers, Site 823.

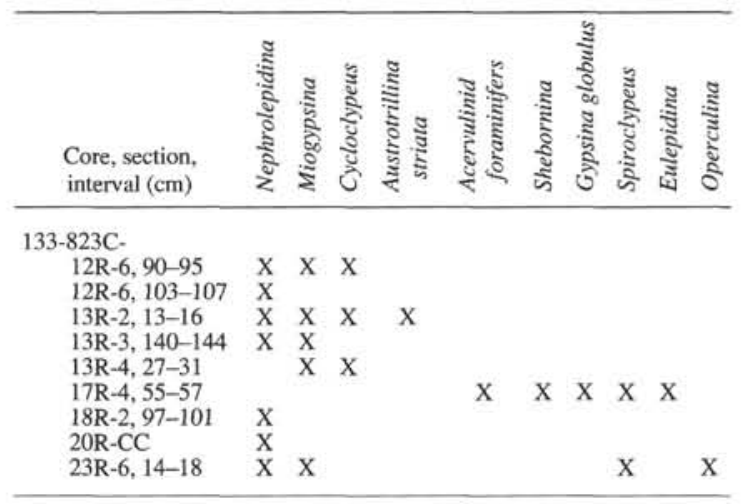

planktonic foraminifers in the samples. In this model, medium-sized Nummulites occur in a somewhat shallower position.

However, one should also take into account that during the Paleogene the surface waters of the Australian Realm were subjected to severe temperature fluctuations, which also controlled the foraminiferal associations (McGowran and Beecroft, 1986). Cooler than subtropical surface-water temperatures for the Paleogene of the Queensland Plateau are indicated by associations dominated by bryozoans, similar to facies described by James and Bone (1991) for the Miocene temperate-water limestones of South Australia. These neritic deposits are characterized by the absence of larger benthic foraminifers and aragonitic bioclasts. In such a case, the occurrence of larger benthic foraminifers, which need waters warmer than $17^{\circ}$ to $20^{\circ} \mathrm{C}$ for reproduction (see Adams et al., 1990, for discussion), may indicate transitional surface-water temperatures (temperate to subtropical), as described for recent deposits of the South American shelf by Carannante et al. (1988). For this reason, the typical Eocene (lower and middle Eocene) shallow- to deep-water faunal succession may be missing some important genera and, as a consequence, show a low diversity at the Queensland Plateau for this interval of time.

\section{Neogene (lower and middle Miocene)}

Because of intense dolomitization at Sites 812,813 , and 814, the record of the original depositional facies is only fragmentary. Thus, our description and interpretation of the larger foraminifer associations concentrate mainly on Sites $811 / 825$ and 824 .

Eight larger benthic foraminifer associations occur in the Miocene section. The vertical succession of these facies at Site 824 is presented in Table 4. 
Table 3. List of samples assigned to different larger benthic foraminifer associations.

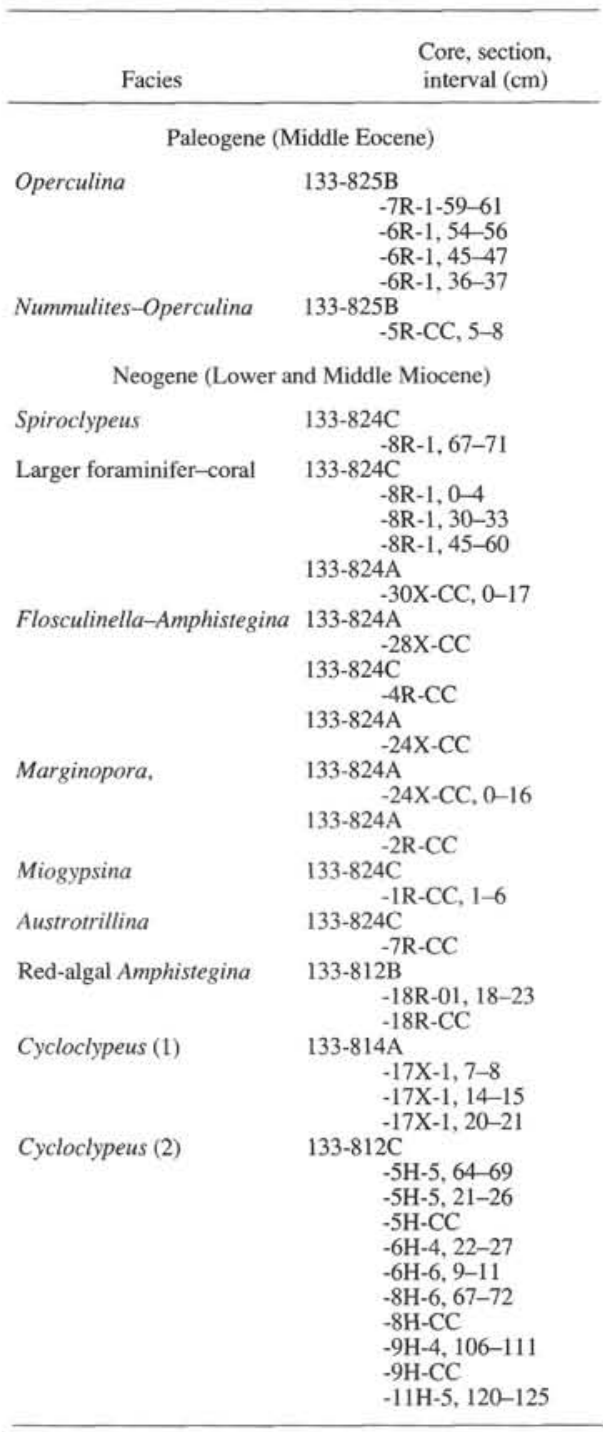

Table 4. Succession of middle Miocene larger benthic foraminifer-bearing facies at Site $\mathbf{8 2 4}$.

\begin{tabular}{l}
\hline \multicolumn{1}{c}{ Facies-sequence, Site 824} \\
\hline (larger benthic foraminifers) \\
Miogypsina Facies \\
Marginopora Facies \\
Flosculinella-Amphistegina Facies \\
Austrotrillina Facies \\
Larger Foraminifer-Coral Facies \\
Spiroclypeus Facies \\
\hline
\end{tabular}

\section{Spiroclypeus Facies}

This facies consists of a packstone with Spiroclypeus, amphisteginid foraminifers, smaller benthic foraminifers, very rare Marginopora (Pl. 4 , Figs. 7 and 8), very rare planktonic foraminifers, debris of articulate red algae, and echinoid debris. Some of the bioclasts are imbricated.

\section{Larger Foraminifer-Coral Facies}

This facies consists of rudstones with frequent-to-abundant Lepidocyclina (Lepidocyclina [Nephrolepidina] praehowchini, L. (N.) sumatrensis, large L. [Eulepidina) ephippioides), frequent Miogypsina (Miogypsinoides) dehaarti, rare Cycloclypeus, rare Marginopora, rare Heterostegina, very rare Borelis, very rare Austrotrillina striata, and amphisteginids, together with smaller benthic foraminifers. Other biogenic components are frequent-to-abundant corals, which are encrusted by acervulinid foraminifers, frequent nodular red algae, and Halimeda.

\section{Flosculinella-Amphistegina Facies}

Wackestones to floatstones with Flosculinella globosa, rare-tofrequent, thick-walled Amphistegina, rare Austrotrillina, rare small Miogypsina, and rare Lepidocyclina (Nephrolepidina). Other components are mollusk debris and debris of red algae and echinoids.

\section{Marginopora Facies}

This facies is a wackestone to floatstone with abundant to very abundant Marginopora, small benthic foraminifers, rare Spirolina, and amphisteginids. Other bioclasts consist of echinoid debris.

A variation of this facies consists of fine-grained bioclastic packstones with abundant small miliolids and rare-to-frequent specimens of Marginopora.

\section{Miogypsina Facies}

This facies consists of a floatstone with abundant large Miogypsina, small amphisteginids, and very rare Lepidocyclina (Nephrolepidina). The larger benthic foraminifers are accompanied by debris of small articulate red algae, mollusk-debris, and rare ostracods. This facies occurs in one sample (Table 3 ) overlying an unconformity that probably represents a flooding surface (hardground with borings infilled with planktonic foraminifers).

\section{Austrotrillina Facies}

This facies is a bioclastic packstone with abundant Austrotrillina striata, rare Flosculinella, rare Marginopora, very rare Lepidocyclina (Nephrolepidina), and very rare Borelis. Other components are miliolids, echinoid debris, and micritized bioclasts.

\section{Red-Algal Amphistegina Facies}

This facies consists of rudstones with abundant nodular, partly fragmented red algae with abundant Amphistegina and Halimeda. The algal nodules have been encrusted by acervulinid foraminifers.

\section{Cycloclypeus Facies}

Two Cycloclypeus-dominated facies occur in the studied samples:

1. Lithified packstones to rudstones with abundant large Cycloclypeus and Katacycloclypeus, abundant planktonic foraminifers, and very rare Miogypsinoides. Other components are mollusk debris, nodular red algae, and rare serpulids.

2. Unlithified packstones with abundant to very abundant large Cycloclypeus, rare-to-frequent Operculina, echinoid debris, rare-tofrequent planktonic foraminifers, and smaller benthic foraminifers.

\section{INTERPRETATION}

\section{Larger Benthic Foraminifer Facies Models for the Miocene}

Different authors have proposed larger benthic foraminifer distribution models for the Neogene (Fig. 4).

Haak (in Wiedicke, 1987) discussed Miocene carbonate build-ups onshore of Borneo. He described reef flats and back-reef areas that 


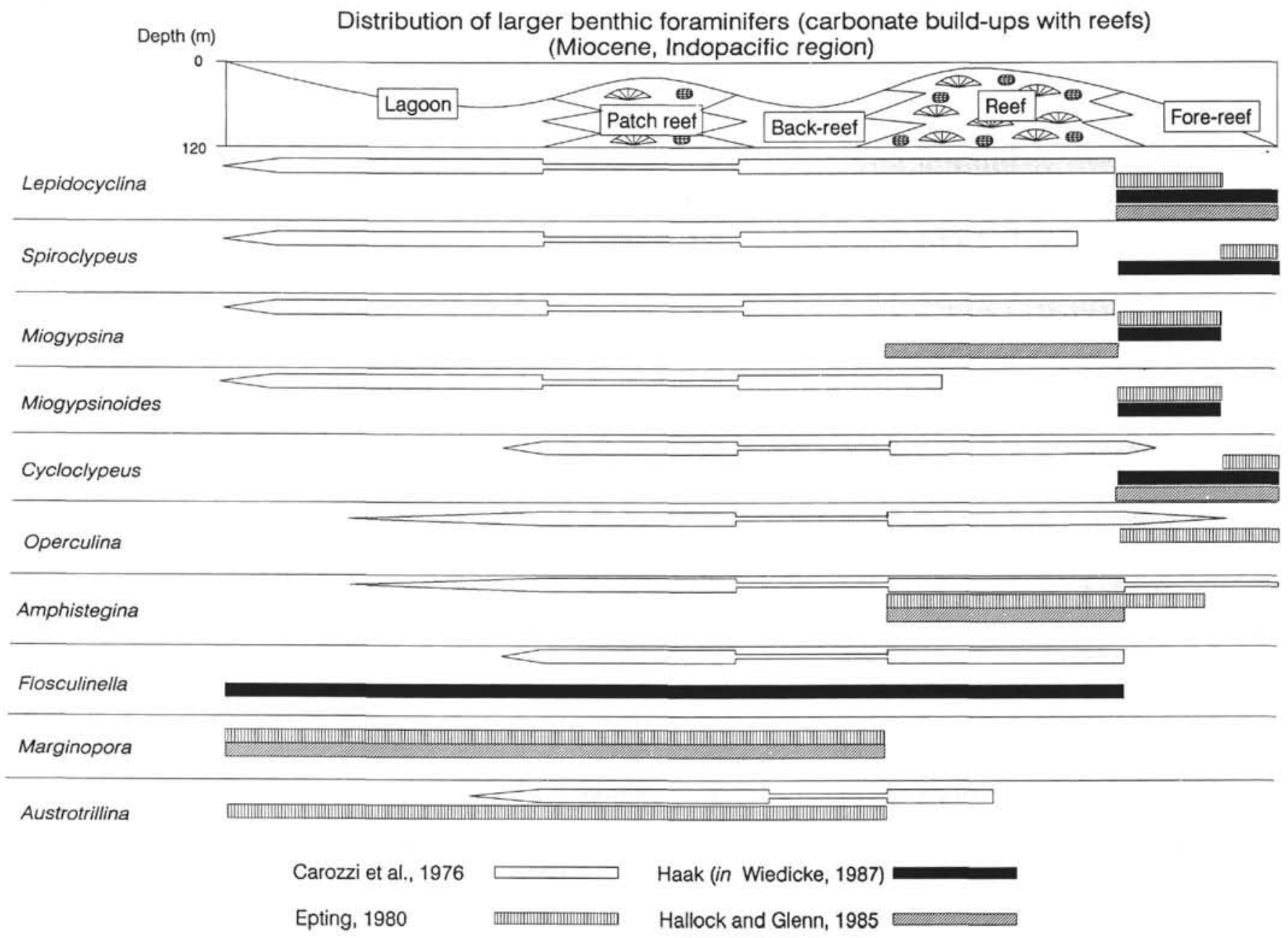

Figure 4. Comparison of different facies models of Miocene neritic carbonates.

contain miliolids, peneroplids, and alveolinids. Miogypsina and Miogypsinoides dominated the assemblages in shallow water down to a depth of $35 \mathrm{~m}$, whereas deeper water zones (maximum depth $65 \mathrm{~m}$ ) were characterized by Cycloclypeus, Lepidocyclina, and Spiroclypeus.

Chaproniere (1975) described faunal associations from Western Australia. He assigned eight different assemblages to three depositional settings within the euphotic zone. The first setting represented open oceanic conditions with Lepidocyclina (Nephrolepidina) howchini and Cycloclypeus eidae in shallow waters with seagrass $(<20$ $\mathrm{m}$ ), and L. (Eulepidina) badjirraensis, and Cycloclypeus eidae in a slightly deeper position. Operculina complanata dominated in deeper water regions (between $50 \mathrm{~m}$ and the base of the euphotic zone). The second setting was a sheltered oceanic environment with $L$. $(E$. ephippioides and Heterostegina borneensis in shallow water with seagrass, and Operculina complanata together with Gypsina howchini in slightly deeper settings (maximum depth $50 \mathrm{~m}$ ).

The third environment is characterized by metahaline conditions with Lepidocyclina (N.) howchini and Marginopora vertebralis as seagrass association and Austrotrillina howchini together with Flosculinella bontangensis in deeper positions. In contrast to the other described facies associations, no reefal facies occurs in the Western Australian deposits, although the formation of a bioclastic sand barrier system eventually led to restricted lagoonal conditions.

Carozzi et al. (1976) proposed a paleoecological reconstruction of the Miocene reefs of the Visayas. This depositional model is an example of a carbonate platform with frontal bio-accumulated buildups (coralgal reefs) and a well-defined lagoonal back-reef setting.
Lepidocyclina, Spiroclypeus, Miogypsina, and Miogypsinoides occur preferentially in these lagoons, where they may form foraminiferal banks. Cycloclypeus, Borelis, Heterostegina, Austrotrillina, Flosculinella, Operculinoides, and Operculina dominate in the main reefs. However, these genera may also be important in lagoonal patch reefs.

Epting (1980) described Miocene carbonate build-ups from offshore Sarawak. He distinguished three main facies. A protected setting contained Sorites, Alveolinella, Marginopora, and Austrotrillina. Under restricted marine conditions, protected areas have been characterized by the abundant occurrence of imperforate benthic foraminifers (miliolids). A "reefoid" environment contains Amphistegina. Shallow, open-marine off-reef zones are characterized by Lepidocyclina, Miogypsina, Miogypsinoides, Amphistegina, Heterostegina, and Operculina. This environment existed either on the seaward slope of the reef complex or on submerged build-ups after active reef growth ceased. Both environments differ by the influx of reef-derived elements in the "background" facies. Moreover, submerged build-ups frequently exhibit facies having abundant rhodoliths. Deeper, openmarine off-reef environments also contain Cycloclypeus, Lepidocyclina (Eulepidina), and Spiroclypeus together with planktonic foraminifers. Within this zone, it is difficult to distinguish between an off-reef setting and a position within a submerged, but still producing, build-up because both facies lack coarse reef debris.

Hottinger (1983) proposed a model that differentiates between hard (high energy) and soft substrates (low energy). The Miocene hard substrate, shallow-to-deep succession is: Baculogypsina, involute Heterostegina, Flosculinella, Nummulites, and Cycloclypeus. The 
soft substrate, shallow-to-deep succession is Sorites, Borelis and Flosculinella, Operculina, and Planoperculina.

Hallock and Glenn (1985) defined three assemblages in carbonate build-ups offshore Palawan. Here, lagoonal environments are characterized by soritids, miliolids, and smaller rotaliines. Shallow-water algal stabilized reef flats contain Miogypsina and Amphistegina. Reef-slope environments contain Lepidocyclina and Cycloclypeus together with planktonic foraminifers.

The main difference among these models is the existence of a reef that acts as a barrier and delimits a well-defined lagoonal setting.

Carozzi et al. (1976) pointed out that reefs only existed in the Miocene build-ups under certain conditions (e.g., enough accommodation space). The authors stated (p. 35) that certain larger benthic foraminifers, which make up part of the reefal assemblages, disappear under nonreefal conditions, while others persist, regardless of the change of environment. Another important aspect of Carozzi's model is the siliciclastic influx in different facies zones (mainly lagoonal) of the mainland-attached depositional systems. This influence does not appear in the other models.

\section{COMPARISON WITH THE MIOCENE QUEENSLAND-PLATEAU NERITIC DEPOSITS}

\section{Spiroclypeus Facies}

Whereas Carozzi et al. (1976) assumed a back-reef setting for the formation of this facies, Hottinger (1983) proposed an "off-reef" position. In the case of the samples studied, such an off-reef position is suggested for this facies because of the presence of planktonic foraminifers.

\section{Larger Foraminifer-Coral Facies}

This facies is dominated by reef-derived material mixed with larger benthic foraminifers, which is indicative of open-marine conditions. The absence of planktonic foraminifers suggests a shallow depositional environment. We suggest that this facies formed on reef talus.

\section{Flosculinella-Amphistegina Facies}

Flosculinella and Amphistegina (thick-walled forms) occur in high-energy environments (e.g., reefs). However, the predominantly muddy matrix of this facies points to a relatively low-energy depositional environment. The absence of planktonic foraminifers may reflect protected conditions. Consequently, we postulate that this facies was deposited in a position proximal to a reef, possibly in a protected back-reef setting, with the larger benthic foraminifers being transported from a higher energy setting.

\section{Marginopora Facies}

According to the different authors and to observations in recent tropical neritic deposits, Marginopora lives attached on sea-grass or hard substrates in shallow-water areas (Jell et al., 1965). One assumes that the Queensland-Plateau facies formed in a similar environment. The facies having abundant miliolids may represent deposition under more restricted conditions (increased salinities; see Murray, 1973).

\section{Miogypsina Facies}

The texture of this facies points to deposition within a low-energy environment, and because it occurs above a flooding surface, we suggest that it may have formed on a drowned platform.

\section{Austrotrillina Facies}

This facies has been assigned to a shallow metahaline lagoonal setting (see Chaproniere, 1975).

\section{Red-Algal Amphistegina Facies}

This facies is similar to the shallow-water algal stabilized reef facies of Hallock and Glenn (1985).

\section{Cycloclypeus Facies}

Whereas Haak (in Wiedicke, 1987) and Epting (1980) described Cycloclypeus from intermediate euphotic depths, Carozzi et al. (1976) related Cycloclypeus to reefs. Chaproniere (1975) described a Cycloclypeus Facies from a maximal water depth of $20 \mathrm{~m}$. Facies having large Cycloclypeus, however, also occur in deeper settings where the individuals are able to survive, but not to reproduce.

In the samples analyzed, Cycloclypeus occurs in combination with Operculina and planktonic foraminifers. For these reasons, the association was assigned to an open-marine, outer-platform setting within the euphotic zone.

\section{CONCLUSIONS}

Two larger benthic foraminifer-bearing depositional systems of differing age were distinguished in sediments constituting the Queensland Plateau: a Paleogene system and a Neogene system. The in-situ occurrence of these larger benthic foraminifer associations at Sites $811 / 825,824,812,813$, and 814 proves that the respective depositional areas were situated within the photic zone $(\sim 0-120 \mathrm{~m}$ depth) during these epochs.

The Paleogene deposits are characterized by abundant Operculina and rare Nummulites in packstones to grainstones, with abundant to very abundant bryozoans. The faunal composition of these facies points to a middle to outer neritic setting in a transitional subtropicaltemperate water setting.

The Neogene deposits contain all characteristic faunal and floral representatives of tropical to subtropical neritic deposits. Based on microfacies analysis and analysis of the larger benthic foraminifer associations, different neritic (inner-to-outer neritic) depositional settings were distinguished (mainly at Sites $811 / 825$ and 824). These range from an off-reef and reef environment to shallower, more protected and restricted areas.

\section{ACKNOWLEDGMENTS}

We are grateful to $\mathrm{H}$. Schaub for his helpful comments about the Nummulites-bearing faunas and to C. G. Adams for critically reading this manuscript and for his helpful suggestions. E. Gottwald gave technical assistance for the difficult thin section preparation. C. Betzler acknowledges financial support by the DFG (Grant Be $1272 / 2-2)$. G. Chaproniere publishes with the permission of the Executive Director, Australian Bureau of Mineral Resources, Geology and Geophysics. We would also like to thank J. Butterlin, P. Quilty, and A. Wonders for their helpful reviews of the manuscript.

\section{REFERENCES}

Adams, C.G., 1970. A reconsideration of the East Indian Letter Classification of the Tertiary. Bull. Br. Mus. (Nat. Hist.), Geol., 19:87-137.

1984. Neogene larger foraminifera, evolutionary and geological events in the context of datum planes. In Ikebe, N., and Tsuchi, R. (Eds.), Pacific Neogene Datum Planes: Contributions to Biostratigraphy and Chronology: Tokyo (Univ. of Tokyo Press), 47-67.

Adams, G.C., Lee, D.E., and Rosen, B.R., 1990. Conflicting isotopic and biotic evidence for tropical sea-surface temperatures during the Tertiary. Palaeogeogr., Palaeoclimatol., Palaeoecol., 77:289-313.

\footnotetext{
Abbreviations for names of organizations and publication titles in ODP reference lists follow the style given in Chemical Abstracts Service Source Index (published by American Chemical Society).
} 
Burns, R.E., Andrews, J.E., et al., 1973. Init. Repts. DSDP, 21: Washington (U.S. Govt. Printing Office).

Carannante, G., Esteban, M., Milliman, J.D., and Simone, L., 1988. Carbonate lithofacies as paleolatitude indicators: problems and limitations. Sediment. Geol., 60:333-346.

Carozzi, A.V., Reyes, M.V., and Ocampo, V.P., 1976. Microfacies and microfossils of the Miocene reef carbonates of the Philippines. Philippine Oil Devel. Comp., Spec. Publ., 1:1-79.

Chaproniere, G.C.H., 1975. Palaeoecology of Oligo-Miocene larger foraminiferida, Australia. Alcheringa, 1:37-58.

1980. Biometrical studies of early Neogene larger foraminiferida from Australia and New Zealand. Alcheringa, 4:153-181.

1981. Australasian mid-Tertiary larger foraminiferal associations and their bearing on the East Indian Letter Classification. BMR J. Aust. Geol. Geophys., 6:145-151.

, 1983. Tertiary larger foraminiferids from the northwestern margin of the Queensland Plateau, Australia. Bull.-Bur. Miner. Resour, Geol. Geophys. (Aust.), 217:31-57.

, 1984. Oligocene and Miocene larger foraminiferida from Australia and New Zealand. Bull.-Bur. Miner. Resour., Geol. Geophys. (Aust.). 188:1-98.

Davies, P.J., McKenzie, J.A., Palmer-Julson, A., et al., 1991. Proc. ODP, Init. Repts., 133: College Station, TX (Ocean Drilling Program).

Epting, M., 1980. Sedimentology of Miocene carbonate buildups, Central Luconia, offshore Sarawak. Bull. Geol. Soc. Malays., 12:17-30.

Hallock, P., and Glenn, E.C., 1985. Numerical analysis of foraminiferal assemblages: a tool for recognizing depositional facies in lower Miocene reef complexes. J. Paleontol., 59:1382-1394.

Hottinger, L., 1983. Processes determining the distribution of larger Foraminifera in space and time. Utrecht Micropaleontol. Bull., 30:239-253.

James, N.P., and Bone, Y., 1991. Origin of a cool-water, Oligo-Miocene deep shelf limestone, Eucla Platform, southern Australia. Sedimentology, 38:323-341.

Jell, J.S., Maxwell, W.G.H., and McKellar, R.G., 1965. The significance of the larger foraminifera in the Heron Island Reef sediments. J. Paleontol., 39:273-279.
Jenkins, D.G., Bowen, D.Q., Adams, C.G., Shackleton, N.J., and Brassell, S.C., 1985. The Neogene: Part 1. In Snelling, N.J. (Ed.), The Chronology of the Geological Record. Geol. Soc. London Mem., 10:199-210.

Luterbacher, H., 1984. Paleoecology of foraminifera in the Paleogene of the Southern Pyrenees. Benthos '83: 2nd Int. Symp. Benthic Foraminifera (Pau, April 1983), 389-392.

McGowran, B., and Beecroft, A., 1986. Neritic, southern extratropical foraminifera and the terminal Eocene event. Palaeogeogr., Palaeoclimatol., Palaeoecol., 55:23-34.

Murray, J.W., 1973. Distribution and Ecology of Living Benthic Foraminiferids: London (Heinemann Educational Books).

Palmieri, V., 1973. Comparison of correlation methods for planktonic and larger foraminifera in the Capricorn Basin, Queensland. Queensl. Gov. Min. J., 74:312-317.

1984. Neogene foraminiferida from GSQ Sandy Cape 1-3R bore, Queensland: a biostratigraphic appraisal. Palaeogeogr., Palaeoclimatol., Palaeoecol., 46:165-183.

Van der Vlerk, J.M., de Bock, J.F., and Sirotti, A., 1973. Biometrical inverstigations on Operculina and Lepidocyclina. Boll. Soc. Paleontol. Ital., 11:86-99.

Van Vessem, E.J., 1978. Study of Lepidocyclinidae from South-East Asia, particularly from Java and Borneo. Utrecht Micropaleontol. Bull., 19:1-163.

Wiedicke, M., 1987. Biostratigraphie, Mikrofazies und Diagenese tertiärer Karbonate aus dem Südchineschen Meer (Dangerous Grounds-Palawan, Philippinen). Facies, 16:195-302.

Wonders, A.A.H., and Adams, C.G., 1991. The biostratigraphical and evolutionary significance of Alveolinella praequoyi sp. nov. from Papua New Guinea. Bull. Br. Mus. Nat. Hist., 47:169-175.

\author{
Date of initial receipt: 27 March 1992 \\ Date of acceptance: 19 November 1992 \\ Ms 133B-210
}



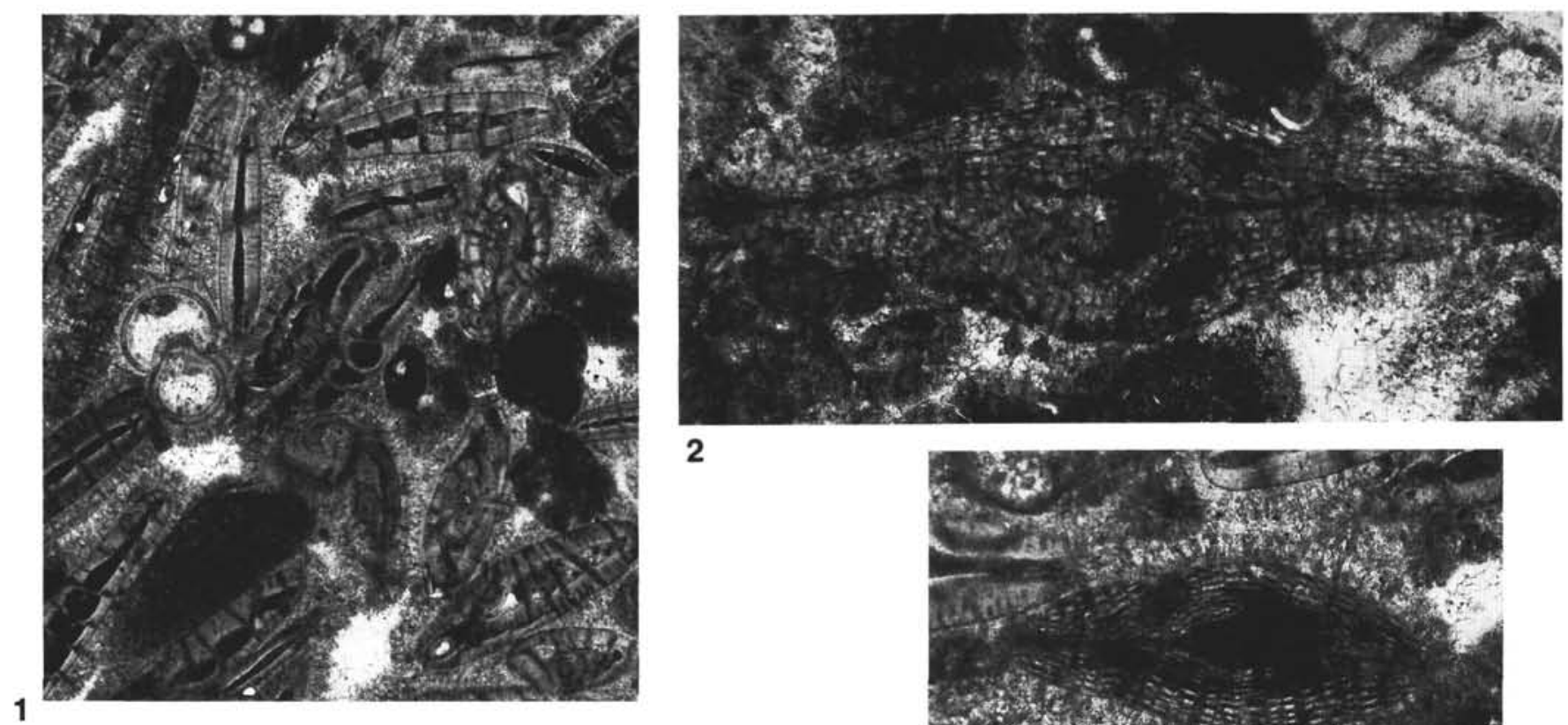

2
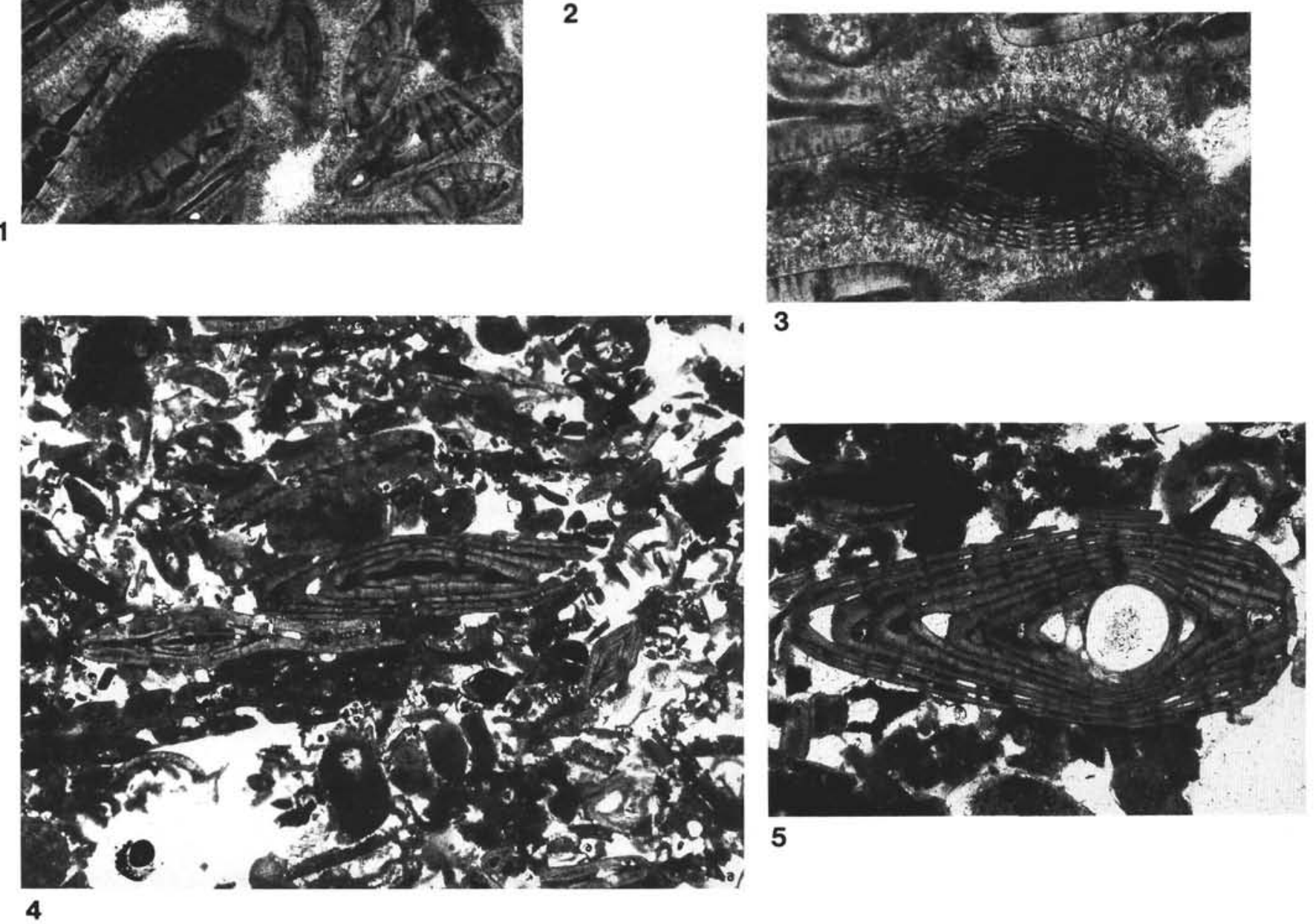

Plate 1. 1. Grainstone with Operculina and Discocyclina; Sample 133-825B-7R-1,59-61 cm, $\times 15$. The grainstone is characterized by two types of cement. The first consists of isopachous fibrous cement, the second is formed by blocky cement, middle Eocene. 2. Discocyclina; Sample 133-825B-7R-1, 59-61 $\mathrm{cm}, \times 52$, middle Eocene. 3. Discocyclina; Sample 133-825B-7R-1, 59-61 cm, $\times 77$, middle Eocene. 4. Nummulites grain- to packstone with abundant bryozoans; Sample 133-825B-5R-CC, 5-8 cm, $\times 7.5$, middle Eocene. 5. Fairly centered axial section of Nummulites; Sample 133-825B-5R-CC, 5-8 cm, $\times 30$, middle Eocene. 

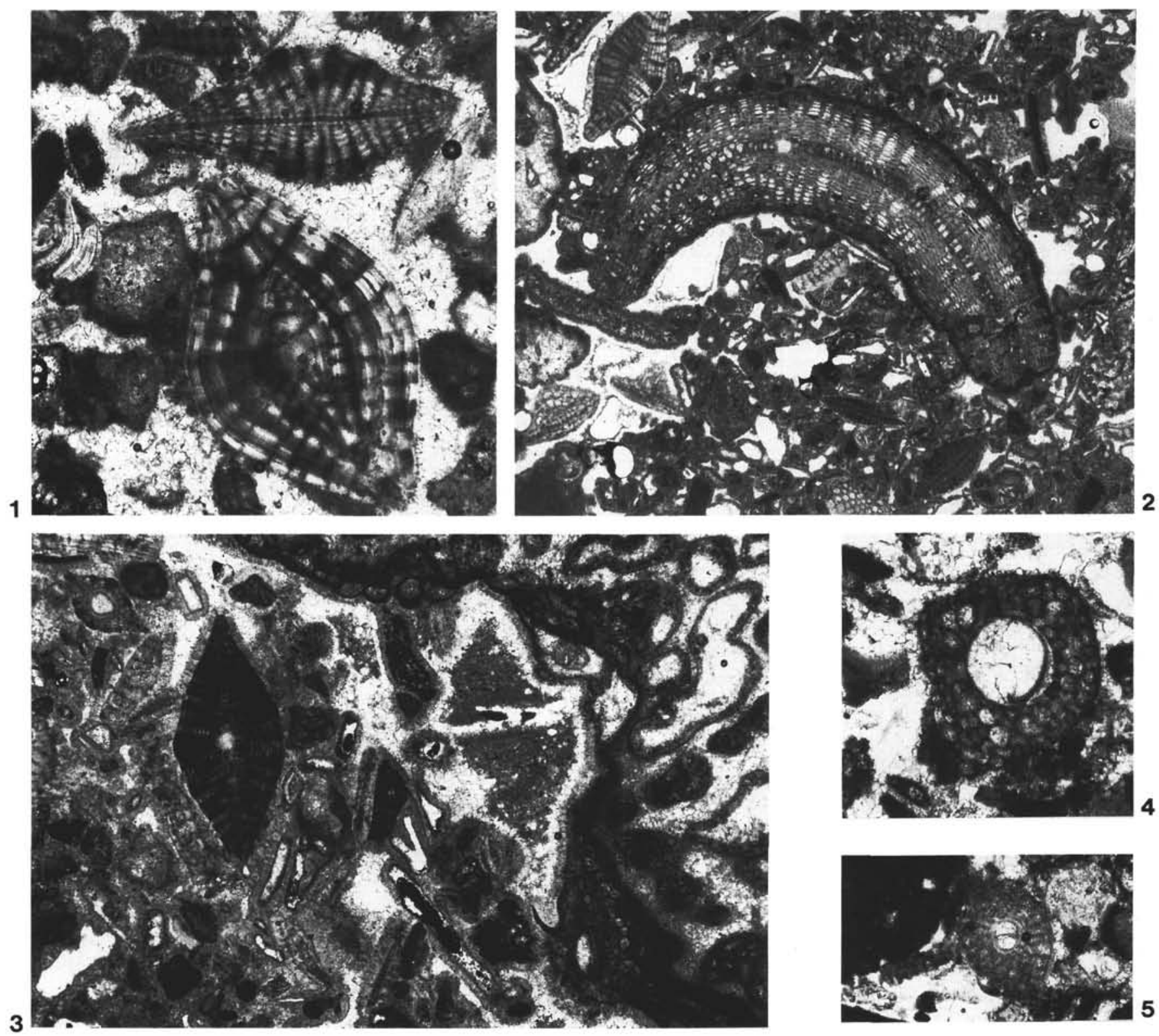

Plate 2. 1. Axial sections of Spiroclypeus and Lepidocyclina (Nephrolepidina sumatrensis); Sample 133-824C-8R-1, 67-70 cm, $\times 30$, lower Miocene. 2. Grain to packstone with Eulepidina, L. (N.) sumatrensis, and Miogypsina (Miogypsinoides) dehaarti; Sample 133-824C-8R-1, 30-33 cm, $\times 7.5$, lower Miocene. 3. Rudstone with $L_{n}\left(N_{\text {. }}\right)$ sumatrensis and debris of corals encrusted by acervulinid foraminifers. A complex diagenetic history is reflected in the cement stratigraphy, with a first generation of isopachous fibrous cement and a second generation of scalenoedric cement. Remaining voids are partially filled in by micritic mud, Sample 133-824C-8R-1, 0-5 cm, x7.5, lower Miocene. 4. Oblique equatorial section of an embryoconch of Lepidocyclina (Eulepidina); Sample 133-824C-8R-1, 0-5 cm, $\times 30$, lower Miocene. 5. Oblique equatorial section of an embryoconch of $L$. (N.) sumatrensis; Sample 133-824C-8R-1, 0-5 cm, $\times 30$, lower Miocene. 

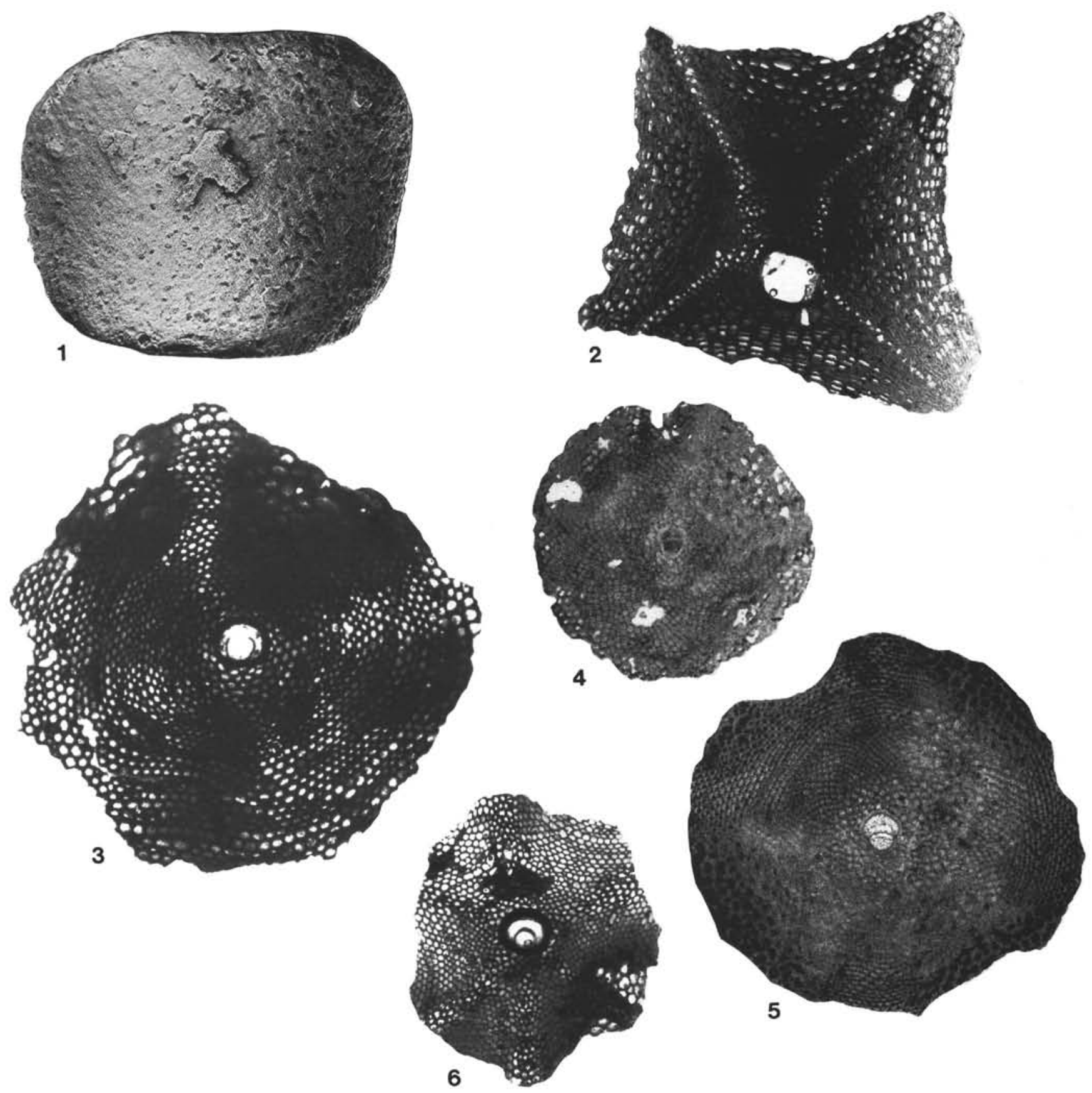

Plate 3. 1. External view of Lepidocyclina (Eulepidina) ephippioides; Sample $133-811 \mathrm{~B}-16 \mathrm{X}-1,110-116 \mathrm{~cm}, \times 19$, lower Miocene. 2. Embryoconch of $L$. (E.) ephippioides; Sample 133-811B-16X-1, 110-116 cm, $\times 10$, lower Miocene. 3. Equatorial section of $L$. (E.) ephippioides (?); Sample 133-811B-15X-CC, $\times 20$, lower Miocene. 4. Equatorial section of $L$. (Nephrolepidina) sumatrensis; Sample 133-811B-16X-CC, $\times 20$, lower Miocene. 5. Equatorial section of $L$. $(N$.$) howchini praehowchini; Sample 133-824A-24X-CC, \times 20$, lower Miocene. 6. Equatorial section of $L .(N$.) howchini; Sample 133-811A-20H-1, 83-88 cm, $\times 20$, middle Miocene. 

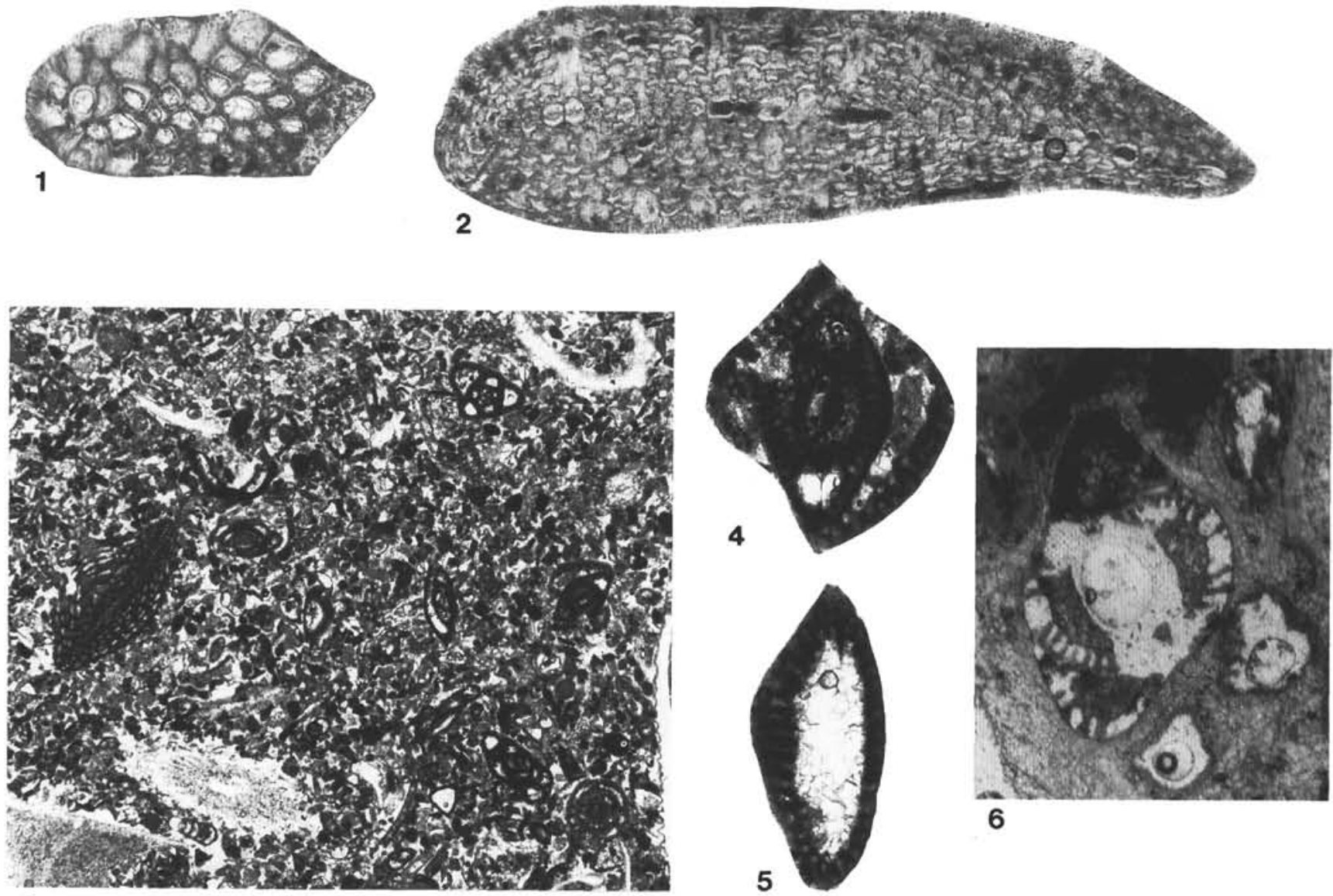

3

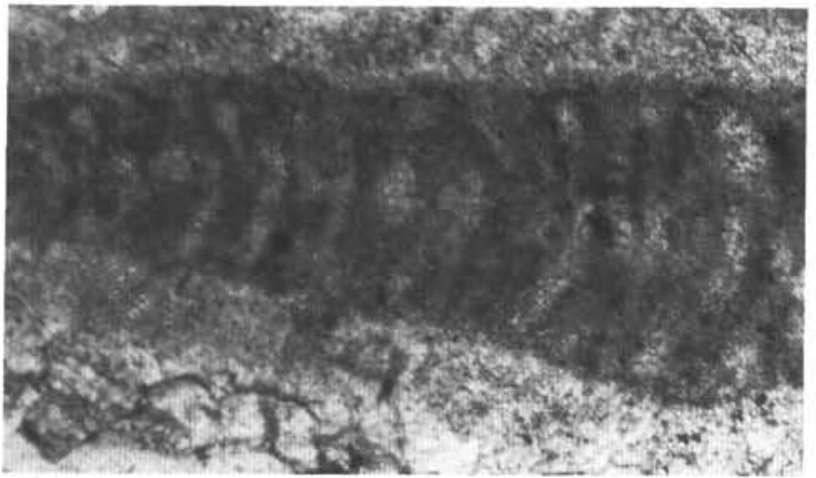

8

Plate 4. 1. Oblique equatorial section of Miogypsina (Miogypsinoides) dehaarti: Sample 133-824C-8R-1, 30-33 cm, $\times 30$, lower Miocene. 2. Miogypsina thecideaeformis; non-centered axial section, Sample 133-824C-IR-CC, $\times 30$, middle Miocene. 3. Packstone with Austrotrillina striata, Flosculinella globulosa, and Lepidocyclina (Nephrolepidina); Sample 133-824C-7R-CC, $\times 12$, lower Miocene. 4. Austrotrillina striata; Sample 133-824C-7R-CC, $\times 32$, lower Miocene. 5. Austrotrillina striata; Sample 133-824C-7R-CC, $\times 38$, lower Miocene. 6. Austrotrillina striata; Sample $133-824 \mathrm{C}-7 \mathrm{R}-\mathrm{CC}, 5-8 \mathrm{~cm}, \times 38$, lower Miocene. 7. Marginopora vertebralis; Sample 133-824C-8R-1, 34-38 cm, $\times 48$, lower Miocene. 8. Amplification of (7) $\times 130$. 

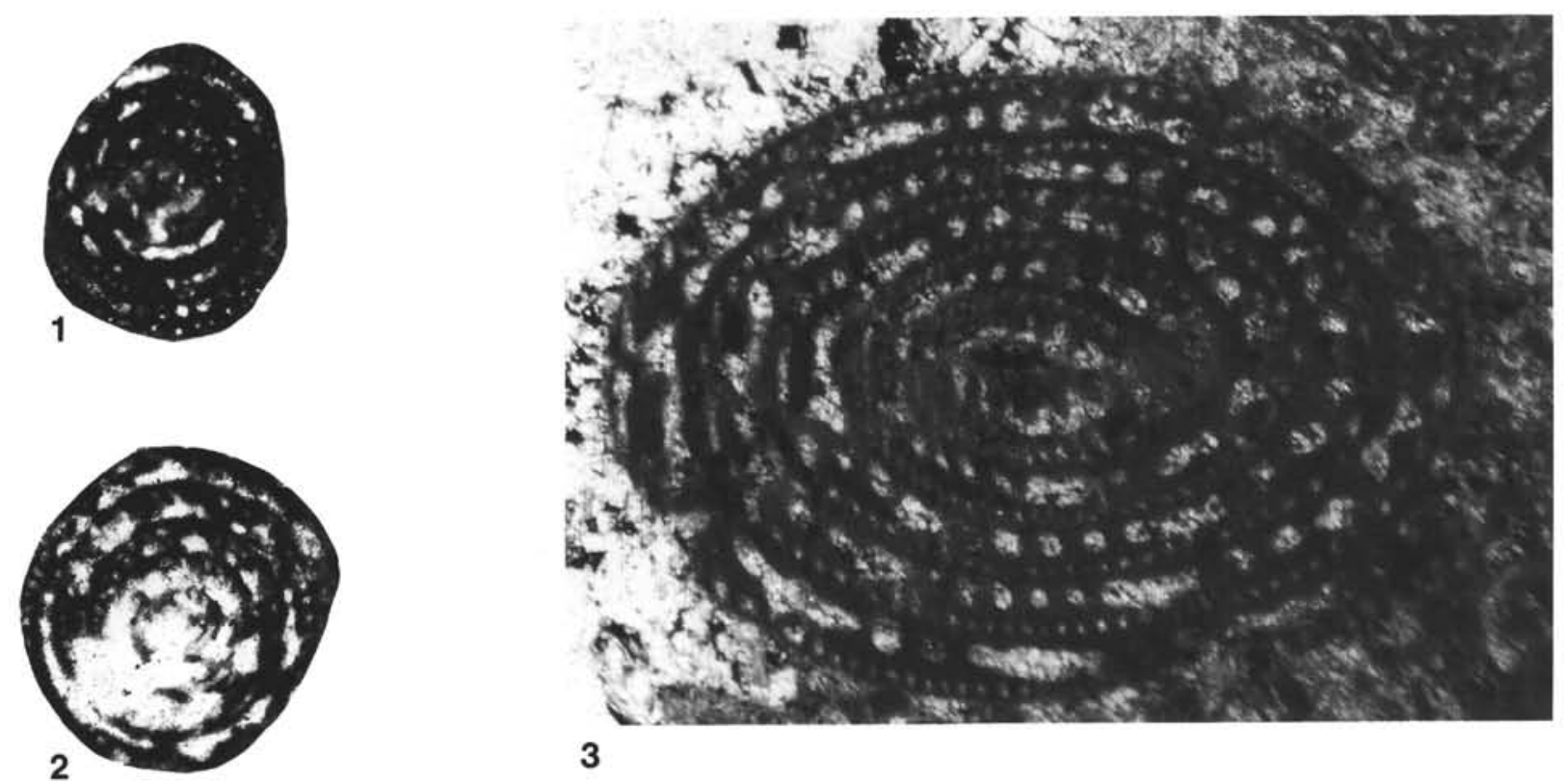

3

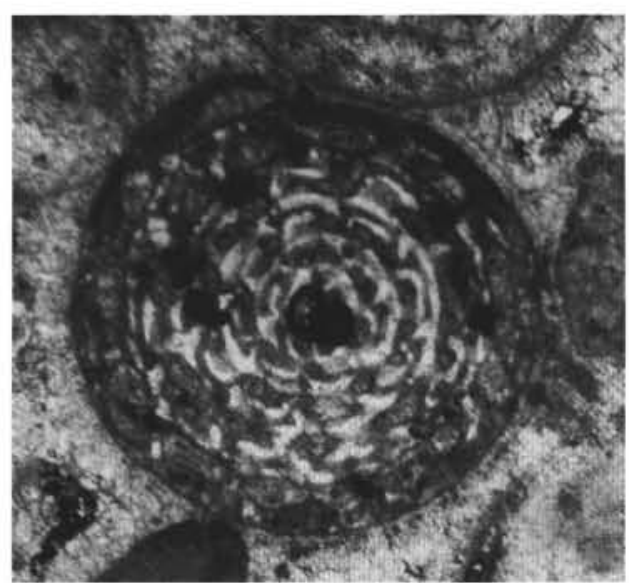

4

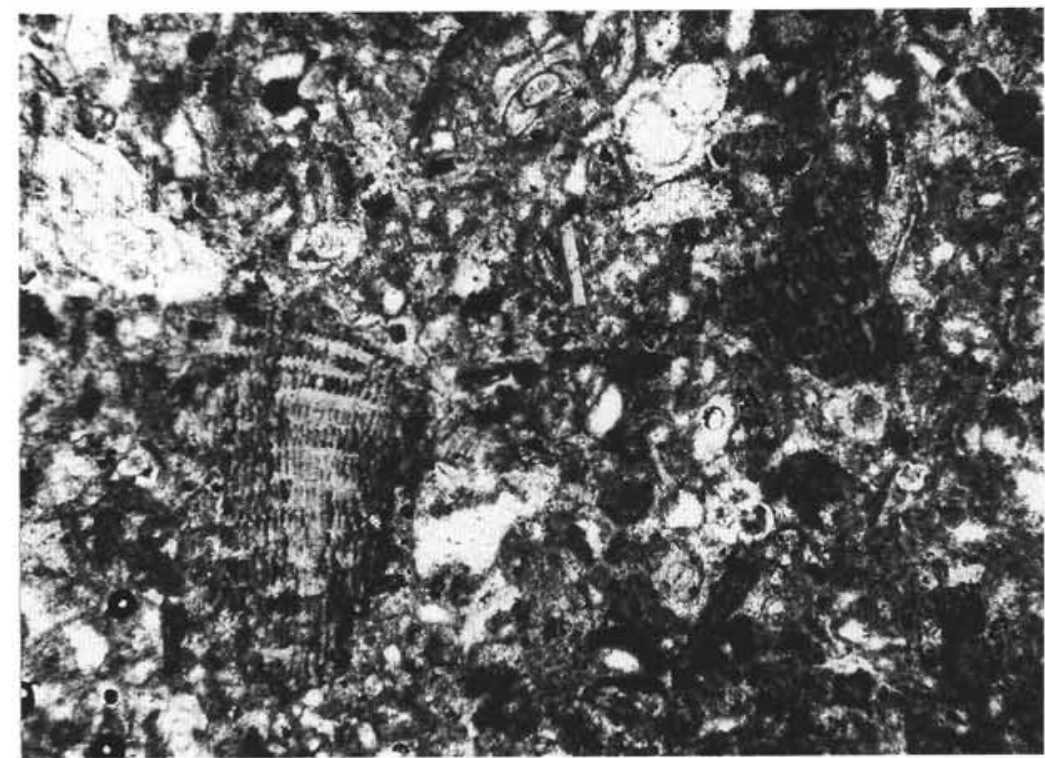

5

Plate 5. 1. Oblique axial section of Flosculinella globulosa; Sample $133-824 \mathrm{~A}-28 \mathrm{X}-\mathrm{CC}, 0-12 \mathrm{~cm}, \times 38$, lower Miocene. 2. Oblique equatorial section of Flosculinella globulosa; Sample 133-824A-28X-CC, $0-12 \mathrm{~cm}, \times 38$, lower Miocene. 3. Tangential section of a slightly ovate to distinctly elongate Flosculinella bontangensis; Sample 133-824C-7R-CC, 5-8 cm, $\times 50$, lower Miocene. 4. Noncentered equatorial section of $F$. bontangensis; Sample 133-824C-7R-CC, 5-8 cm, $\times 40$, lower Miocene. 5. Pliocene float- to rudstone with reworked Lepidocyclina (Eulepidina) (?); Sample 133-824A-11H-CC, $\times 38$. 